\title{
Analysis of Factors Affecting Share Prices: The Case of Bahrain Stock Exchange
}

\author{
Taimur Sharif ${ }^{1}$, Harsh Purohit $^{2} \&$ Rekha Pillai $^{3}$ \\ ${ }^{1}$ Department of Business Administration, ALHOSN University, Abu Dhabi, UAE \\ ${ }^{2}$ SBI School of Commerce and Banking, Banasthali University, Rajasthan, India \\ ${ }^{3}$ Synergy University, Dubai Campus, Dubai, UAE \\ Correspondence: Taimur Sharif, Department of Business Administration, ALHOSN University, Abu Dhabi \\ 38772, UAE. Tel: 971-2-4070-608. E-mail: t.sharif@alhosnu.ae
}

Received: December 18, 2014

Accepted: December 31, 2014

Online Published: February 25, 2015

doi:10.5539/ijef.v7n3p207

URL: http://dx.doi.org/10.5539/ijef.v7n3p207

\begin{abstract}
The 2007 global financial crisis caused unprecedented upheavals in the global stock markets and has shaken investor's confidence due to the turbulent fluctuations and volatilities in stock prices. The present study is instrumental in identifying the main determinants affecting share prices in the Bahrain financial market. The study analyzes a panel data set of 41 companies listed in the Bahrain stock exchange for the period 2006-2010. The year 2006 is used as the first year of data collection as most of the companies were incorporated in 2005. Since the Bahrain bourse witnessed a turbulent period during the first half of 2010 due to political unrests causing $25.5 \%$ slump in the aggregate value of traded shares in the first half of 2010 and $7.59 \%$ drop in the Global Bahraini Index in the following year, the post-2010 period was deliberately ignored in this study. The estimation method is based on pooled OLS regression with robust standard errors, fixed effects and random effects models. Eight firm specific variables namely return on equity, book value per share, earnings per share, dividend per share, dividend yield, price earnings, debt to assets and controlled by firm size, have been studied to infer their impact on market price of shares in the respective market. The results indicate that the variables return on equity, book value per share, dividend per share, dividend yield, price earnings, and firm size are significant determinants of share prices in the Bahrain market. A high $\mathrm{R}^{2}(0.80)$ revealed under both the applied models further documents the significant impact of these variables on the market price of shares. This suggests that investors can make optimum investment decisions and be assured fair returns if they consider these determinants which have evolved to be the significant contributors to the market price of shares in Bahrain.
\end{abstract}

Keywords: market price of shares, fixed effect and random effect, determinants

\section{Introduction}

The global financial crisis which affected the world economy by the end of 2007 caused extreme volatility and turbulence in the stock market. According to Rudd (2009) global equity markets have lost approximately US\$32 trillion in value since their peak. Before the global financial crisis, the investment trend was focused towards the stock market where investors kept a constant eye on rising and falling shares as it was a source of yielding significant returns to investors. Investment in shares has also been a source of finance for fulfilling firm requirements such as expansion and diversification. It is a generally accepted phenomenon that investors are risk averse and the volatility of their investments cause great concern to them as it is a measure of the intensity of risk they bear. However, from an investor's point of view it is advisable to have knowledge and awareness about the determinants of share price in order to make an optimum investment decision. Scholars have attributed several internal factors and external factors as factors affecting stock price. The company specific or internal factors are company performance, a change in the board structure, asset position, dividends and earnings. The external factors include governmental regulations, business cycle, investor's attitude, market conditions, natural calamities and contingencies like strikes, lock outs etc. Investors have also been advised to be aware of the "Value Investing Strategy" a technique originally propounded by Graham and Dodd (1934). This is another successful investment strategy resorted to especially after the current 2007 global financial crisis and according to this strategy the investor has to examine firms with a low price earnings stocks, low price-to-cash-flow ratio or low price to book ratio stocks as it is assumed that these stocks may outperform growth stocks. Sharma (2011) 
suggests that there are two approaches namely the fundamental approach and technical approach for predicting share prices. The former predicts share price on the basis of financial, environmental and managerial factors, whereas the latter studies the past trends in predicting future share price. Therefore, it is imperative for investors to be knowledgeful about the different approaches and factors surrounding their investment decisions.

In light of these facts, the present study attempts to investigate the impact of eight variables on the market price of shares of firms listed in the Bahrain Stock exchange. The remaining part of the study has been structured as follows: Section 2 emphasizes the importance and objective of the study while section 3 relates to the prior studies conducted on the relevant topic. Section 4 highlights the data collection and methodology and Section 5 devotes itself to the analysis and findings. Section 6 concludes the paper with conclusions, recommendations and limitations thus offering a pathway for further research.

\section{Importance and Objective}

The present study is significant in the sense that it will be the first study to highlight the determinants of stock prices in Bahrain. Since Bahrain is one of the emerging economies, the determinants identified will provide knowledge to the potential investors about the key factors affecting share prices in the country and accordingly assist them in optimizing their investment strategy. The motivation for this study mainly arises from a comment made by Al-Ajmi (2008) that the Bahraini investors are comparatively less risk tolerant than non-Bahrainis. Also, the oil booms reported prior to the global crisis channeled most of the surplus cash from the Middle East into real estate sector or in financial assets with the assistance of an external investment consultant. This income boom also saw the rise of a new investment channel which is the corporate assets overseas or other large blue chip companies. However, this new wave of investment brought with it innumerable challenges with many of the corporate investors suddenly being entangled in a vicious circle of uncertainty especially with the advent of the global crisis. Therefore the main aim of the current study is to enlighten the investors about the key indices which can assure them at least nominal and fair returns on their investment. The stock market and companies can benefit from this study as it will highlight those factors which are perceived by an investor as share price determinants. Once these factors or variables are identified the companies can strive hard in maximizing the value of the aforesaid variables that are deemed significant for investment decisions.

\section{Review of Prior Studies}

The determinants of share price was initiated by Collins (1957) for the US market and he identified dividend, net profit, operating earnings and book value as the prominent factors affecting share prices in the US. Ever since, a significant body of theoretical and empirical literature has evolved that considers the determinants of market price of shares. Irfan and Nishat (2002) identified factors exerting impact on the share prices in Karachi Stock Exchange for the period between 1981 and 2000. The study employed cross-sectional weighted least square regression and analyzed the impact of six variables viz. dividend yield, payout ratio, size, asset growth, leverage and earning volatility on share prices. Of these the payout ratio, size, leverage and dividend yield emerged as the significant factors affecting the stock market prices in Karachi. This suggests that firm specific factors have a significant impact on market price of shares.

In the same vein, Das and Pattanayak (2009) examined 30 shares constituting the Bombay Stock Exchange Sensitivity Index in order to study the factors affecting stock price movements. The analysis revealed that higher earnings, return on investment, growth possibility and favorable valuation have positive impacts on the market price of shares while higher risk and volatility have inverse impacts. Building on the same lines, Nirmala, Sanju and Ramachandran (2011) used panel data and examined three sectors namely auto, healthcare and public sector undertakings over the period 2000-2009 in order to infer the main factors affecting share prices in India. The study employed the fully modified ordinary least squares method and results revealed that dividend, price-earnings ratio and leverage are major determinants of share prices for all the sectors under consideration.

Continuing the chain of research, Khan et al. (2011) analyzed the impact of dividend policy on Stock prices in Malaysia after controlling for factors such as earnings per share, profit after tax and return on equity. The research applied fixed and random effect models on a panel data for 55 companies listed at KSE-100 Index for the period of 2001-2010. Results revealed that dividend yield, earnings per share, return on equity and profit after tax are positively related to stock prices while retention ratio have negative relation with stock prices and significantly explains the variations in the stock market prices.

A more focused study of the impact on dividends (proxied by dividend yield and dividend payout) along with other control variables on share prices were studied by Okafor and Mgbame (2011) in the Nigerian market. The multivariate regression analysis was applied on 10 firms for a eight year period from 1998-2005. Results revealed a negative impact of dividend yield on share price changes while dividend payout revealed inconsistent 
results of positive and negative relationships during the different years studied. Similar studies conducted by Black and Scholes (1974), Capstaff, Klaeboe, and Marshall (2004) and Pani (2008) also found a positive relationship between dividend policy and stock returns. However Baskin (1989) posits a negative relationship between dividend yield and dividend payout on share price changes. This is mainly attributed to the dividend irrelevant hypothesis and the notion among investors that dividend payments are the outcome of the past performance of the firm rather than a reflection of future performance. Similar views related to the irrelevance concept of dividend was expressed by Uddin (2003), Denis and Osobov (2008) and Chen and Dhiensiri, (2009) and in their study of Bangladesh, New Zealand and Nigerian market respectively.

Another significant and positive determinant of stock prices which emerged in the studies conducted by Balkrishnan (1984), Zahir and Khanna (1982) and Sharma (2011) was the book value per share. The studies suggest that a higher book value per share depicts a sound financial performance of the company as book value is a major representation of owners' funds. This in turn affects the stock prices in a positive way. A review of the above studies and findings suggest that firm specific factors (internal factors) have significant impact on the market price of the share. This shows that investors are continuously scrutinizing the performance of the company in order to base their future investment decisions.

Deviating from the above Somoye, Akintoye, and Oseni (2009) conducted a survey on 130 companies traded in the Nigerian stock exchange between 2001 and 2007 in order to analyze the impact of various macro economic factors on the market price of shares. The study employed OLS regression and regressed stock prices on earnings per share, dividend per share, oil price, gross domestic product, lending interest rate and foreign exchange rate on stock price. All the variables revealed a positive correlation to stock prices with the exception of lending interest rate and foreign exchange rate. Similar findings were echoed by Zhao (1999) studied the relationships among inflation, industrial output and stock prices in the Chinese economy for the period 1993-1998. Results revealed a negative relationship existing with both the variables studied on market price per share.

Meanwhile Al-Qenae et al. (2002) made a significant contribution to the topic by basing his research on the GCC market. He analyzed the impact of the effect of earnings and other macroeconomic variables on the stock prices of Kuwait Stock Exchange during the period 1981-1997. The macroeconomic variables examined were gross national product (GNP), interest rate, and inflation. The study found that earnings and GNP were positively related to stock prices (Midani, 2001) while inflation and interest rate showed a significant negative impact on the stock prices in Kuwait. The reason attributed for the effect in Kuwaiti shares is that the Kuwait share market is highly responsive to the sentiments of public and external events. This suggests the extreme vigilance and scrutiny of external factors by the people of Kuwait while basing their investment decisions. The United Arab Emirates (UAE) economy was also studied from 1995-2005 to infer the most prominent factors affecting stock price in the respective market (Al-Tamimi, Alwan, \& Rahman, 2011). The ordinary least squares regression revealed that earnings per share had a significant impact on stock prices in the UAE followed by money supply and GDP. It suggests that investors rely on the earnings per share to judge the efficiency and credibility of the company, therefore it is recommended to adopt those steps which can improve the earnings per share of firms. Similar studies focusing the impact of macro-economic variables on share price were studied by Mukherjee and Naka (1995), Chaudri and Smiles (2004) and Allahawiah and Al Amro (2012).

A general overview of prior studies discussed above on the investigation of the most prominent factors affecting share prices reveals that dividends, earnings per share, price earnings ratio, debt policy, GDP and firm size hold substanatial roles in influencing the same. This suggests that dividend paying firms are better valued by investors as every investor prefers a consistent dividend policy. Also shares with higher Price earnings ratio indicate that such firms will have a promising future in the eyes of investors. Leverage is another imperative element affecting share prices and this suggests that investors attach more value to those firms which employ less debt as increased of debt minimizes the earnings of the stakeholders. Stakeholders also prefer firms which have high earnings per share as it ensures them a better return on the share. Return on Equity is also assumed to hold an important position as it assures the shareholders the amount earned on their investment.

Inspite of the emergence of several studies on the related topic, the findings reveal a mixed opinion regarding their positive or negative impact each makes on market price. We also cannot find a general consensus in the factors affecting the market price of shares as they are the joint outcome of both micro and macro factors. A gap is also noticed in the regions analyzed, and a review of prior studies reveal the absence of research on this topic in the Bahrain economy. This paper will therefore fill the gap by conducting a comprehensive study of eight firm specific factors such as earnings per share, dividend yield, dividend per share, book value per share, debt to assets , price earnings ratio and firm size to determine their extent of impact on the share prices in the Bahrain economy. 


\section{Data Collection and Methodology}

\subsection{Data}

The data for the study was retrieved from the Bahrain stock exchange website namely www.bahrainbourse.net. At present 48 companies are listed in the stock exchange and the companies fall under the category of Commercial Banks, Investment services, Insurance companies, Industrial sector, services, tourism and non Bahraini companies. Panel data for the years ranging from 2006-2010 has been constructed and 41 companies have been included in the study with a total number of 167 observations. The remaining 7 companies have been excluded only due to lack of availability of data for a five year period. The year 2006 has been used as the first year of data collection as most of the companies were incorporated during the year 2005, whereas, the year 2010 has been used as the final point of data collection as the Bahrain bourse witnessed a turbulent period during the first half of 2010 due to the political unrest that extended to the capital city of Manama (Al Bawaba, 2011). As a result, aggregate value of shares traded slumped to 52.3 million Bahraini Dinars from 70.2 million dinars in the first half of 2010. As per the Global Investment House the Global Bahraini Index dropped by $7.59 \%$ as it ended at 107.21 points. Therefore to control for such external factors, the years prior to the unrest has been employed in this study. The total number of observations ought to be $205(41 * 5)$, however negative values for price earnings and other missing figures totals the observations to 167 . Panel data has been constructed due to its inherent merits over cross sectional data. Baltagi $(2001$, p. 6) voices his opinion over panel data as s construction that gives "more informative data, more variability, less co-linearity among the variables, more degrees of freedom and more efficiency."

\subsection{Formulation of Research Hypotheses}

A review of prior studies has resulted in several testable hypotheses. Table 1 provides an overview of the variables used, definition of variables employed and the hypothesized sign.

Table 1. Summary of research hypotheses and proxy variables

\begin{tabular}{|c|c|c|c|}
\hline Variables & Definition & Symbol & Expected Sign \\
\hline \multicolumn{4}{|l|}{ Independent Variables } \\
\hline Return on equity & Net Income / Shareholders equity & ROE & $\mathrm{H} 1(+)$ \\
\hline Book value per share & Total shareholders' equity/Number of shares outstanding & BVS & $\mathrm{H} 2(+)$ \\
\hline Earnings per share & Net Income/Number of shares outstanding & EPS & $\mathrm{H} 3(+)$ \\
\hline Dividend per share & Dividends paid/Number of shares outstanding & DPS & $\mathrm{H} 4(+)$ \\
\hline Dividend yield & Dividen per share/price per share & DY & $\mathrm{H} 5(-)$ \\
\hline Price earnings & Stock price/EPS & $\mathrm{PE}$ & $\mathrm{H} 6(+)$ \\
\hline Debt to total assets & Total debt/Total Assets & DA & $\mathrm{H} 7(-)$ \\
\hline \multicolumn{4}{|l|}{ Control Variable } \\
\hline Firm size & $\begin{array}{l}\text { Market capitalization calculated as Market price of share *number } \\
\text { of shares outstanding }\end{array}$ & Log MCAP & $\mathrm{H} 8(+)$ \\
\hline \multicolumn{4}{|l|}{ Dependent Variable } \\
\hline Market price of share & Closing share price as at $31^{\text {st }}$ December for the years studied & MPS & \\
\hline
\end{tabular}

\subsection{The Empirical Model}

In line with prior studies that examine the relationship between the firms' internal factors and market price of share, the following regression specification is used.

$$
M P S=f(I F, C V)
$$

Where MPS is the market price of firms which is a function of IF (Internal factors variables) and CV (Control variables). Rashid (2008) advocates that the usage of control variables adds robustness to the model by making the results more reliable as they are vital in establishing and enhancing the relationship between the independent and dependent.

The general model intended to be employed in our study to test the alternate hypothesis can be specified as follows:

$$
\begin{aligned}
& M P S=\gamma_{0}+\gamma_{1} R O E_{i t}+\gamma_{2} B V S_{i t}+\gamma_{3} E P S_{i t}+\gamma_{4} D P S_{i t}+\gamma_{5} D Y_{i t}+\gamma_{6} P E_{i t} \\
& +\gamma_{7} D A_{i t}+\gamma_{8} \log M C A P_{i t}+\varepsilon_{i t}
\end{aligned}
$$


Where: (i) refers to the firm studied while (t) refers to time period and the variables already being defined in Table 1.

\subsection{Methodology}

In section 4.2 eight testable hypotheses with their expected sign were formulated and these selected variables will thus constitute our general model to be tested in order to determine the main factors which affect market price of shares in Bahrain. The regression results will be obtained using a statistical package namely STATA 12. Several diagnostic tests such as normality tests, correlation statistics and variance inflation factor techniques will be employed to ascertain the degree of collinearity among the variables. In order to estimate Equation (2), two estimation methods have been applied from econometrics. For comparison purpose, the first method is the Pooled Ordinary Least Square (POLS). To correct for any possible heteroscedasticity we run the POLS regressions with robust standard errors. The Wald test statistics reject the null hypothesis that the parameters in the regression equations are jointly equal to zero.

The second estimation method and that commonly used in panel data analysis is the fixed effects (FE) and the random effects (RE) models. A fixed group effect model examines group differences in intercepts, assuming the same slopes and constant variance across entities or subjects. Since a group (individual specific) effect is time invariant and considered a part of the intercept, the error term $\left(\mathrm{e}_{\mathrm{i}}\right)$ is allowed to be correlated to other regressors. A random effect model, by contrast, estimates variance components for groups (or times) and error, assuming the same intercepts and slopes. Also, the error term should not be correlated with any other explanatory variables in the study. The Hausman specification test is employed to compare fixed effect and random effect models. If the null hypothesis that the individual effects are uncorrelated with the other repressors' in the model is not rejected, a random effect model is better than its fixed counterpart (Park, 2009, p. 4). The Hausman specification test compares the FE and RE and the test assumes that the FE and RE estimates should not differ systematically (Al-Malkawi \& Abdullah, 2011). If the null hypothesis is not rejected the RE estimator is more appropriate otherwise the FE estimator (see, Verbeek, 2000; Greene, 2003).

\section{Empirical Results, Analysis and Findings}

The data collected is first checked for normality and Shapiro-Wilks normality test which reveal a P-value $=0.48$ which is statistically insignificant, thus unable to reject the null hypothesis that the distribution is normal. Thus our usable sample consists of 224 firm year observations derived from all the 28 companies with data available for the years 2005-2012. Table 2 below shows a detailed description of the summary statistics of the independent variables used in the study. The mean, standard deviation, minimum and maximum values for the independent variables studied have been reported in Table 2.

Table 2. Summary statistics of independent variables

\begin{tabular}{lcccc}
\hline Variable & Mean & Standard deviation & Minimum & Maximum \\
\hline ROE & 0.0614 & 0.3193 & -3.005 & 0.455 \\
BVS & 0.5452 & 0.4900 & 0.041 & 2.650 \\
EPS & 0.0340 & 0.1072 & -1.026 & 0.600 \\
DPS & 0.0225 & 0.0219 & 0 & 0.151 \\
DY & 0.0437 & 0.0338 & 0 & 0.229 \\
PE & 14.532 & 13.428 & 2.660 & 99.17 \\
DA & 0.4451 & 0.3112 & 0 & 1.813 \\
Log MCAP & 7.8490 & 0.8469 & 5 & 9.000 \\
\hline
\end{tabular}

In Table 2 above, it is worth noting that there is a wide variation in the minimum and maximum values for PE $(\min =2.66$ and $\max =99.17)$. This suggests that people are willing to pay a huge premium for well performing companies while they are reluctant to invest in underperforming firms. It is also noteworthy to analyze the statistics related to dividend policy which is proxied by dividend yield and dividend per share. Here also we can find a respectable difference in the minimum and maximum values due to the fact that there are companies which are not paying dividends at all. However, major differences are not seen in the values reported for Log MCAP ( $\min =5, \max =9$ ). This reveals that majority of the companies studied have relatively the same size. The mean EPS and DPS (0.03 and 0.02) reported is not a convincing figure for the investors and this minimal figure can be attributed to the effect of the global financial crisis. In an attempt to detect multicollinearity, a correlation matrix was constructed to infer the extent of correlation among the variables studied. Table 3 below shows the 
results of the matrix.

Table 3. Correlation matrix for dependent and independent variables

\begin{tabular}{lccccccccc}
\hline & MPS & ROE & BVS & EPS & DPS & DY & PE & DA & Log MCAP \\
\hline MPS & 1.000 & & & & & & & & \\
ROE & 0.157 & 1.000 & & & & & & & \\
BVS & 0.792 & -0.135 & 1.000 & & & & & & \\
EPS & 0.310 & 0.324 & 0.249 & 1.000 & & & & & \\
DPS & 0.433 & 0.487 & 0.255 & 0.532 & 1.000 & & & & \\
DY & -0.094 & 0.258 & -0.028 & 0.217 & 0.540 & 1.000 & & & \\
PE & -0.028 & -0.229 & -0.102 & -0.256 & -0.220 & -0.194 & 1.000 & & \\
DA & 0.075 & 0.141 & -0.014 & -0.151 & -0.071 & -0.032 & 0.099 & 1.000 & \\
Log MCAP & 0.224 & 0.289 & -0.041 & 0.131 & 0.208 & 0.013 & -0.064 & 0.483 & 1.000 \\
\hline
\end{tabular}

Drury (2008) documents that if the muticollinearity among two variables is $70 \%$ and above, then it is a case of concern. In the present study, we cannot find any severe cases of multicollinearity as the maximum correlation is $54 \%$ between dividend yield and dividend per share. This is because, both are proxies for dividend policy and in order to eliminate their intensity, we have included other independent variables and control variables. Several researchers namely Husseiney et al. (2010), Baskin (1989) and Allen and Rachim (1996) have employed two measures of dividend policy simultaneously to check the independent effect of each variable on share price. A VIF test conducted to further check the extent of multicollinearity among the independent variables revealed a mean VIF of 1.59 in Table 4 which is very small (less than 10, the rule of thump) thus affirming the absence of any multicollinearity.

Table 4. VIF test

\begin{tabular}{lll}
\hline Variables & VIF & I/VIF \\
\hline DPS & 2.56 & 0.3908 \\
ROE & 1.63 & 0.6146 \\
DY & 1.56 & 0.6417 \\
EPS & 1.54 & 0.6492 \\
LOGMCAP & 1.51 & 0.6602 \\
DA & 1.48 & 0.6737 \\
BV & 1.32 & 0.7547 \\
PE & 1.14 & 0.8743 \\
Mean VIF & 1.59 & \\
\hline
\end{tabular}

Table 5 below highlights the estimation results of POLS regression and fixed effects (FE) and random effects (RE) regression. In order to control for heteroskedasticity, the OLS regression was run with robust standard errors.

Table 5. Results of OLS, FE and RE regression

\begin{tabular}{|c|c|c|c|}
\hline \multicolumn{4}{|c|}{ Dependent variable - Market Price of Shares(MPS) } \\
\hline \multirow[b]{3}{*}{ Independent Variables } & Model 1 & \multicolumn{2}{|c|}{ Model 2} \\
\hline & (POLS) & Fixed Effects & Random Effects \\
\hline & $\begin{array}{c}\text { Coefficient } \\
\text { (p value) }\end{array}$ & $\begin{array}{c}\text { Coefficient } \\
\text { (p value) }\end{array}$ & $\begin{array}{c}\text { Coefficient } \\
\text { (p value) }\end{array}$ \\
\hline \multirow[t]{2}{*}{ ROE } & 1.306 & 2.367 & 1.510 \\
\hline & $(.003)^{* * *}$ & $(0.001)^{* * *}$ & $(0.000) * * *$ \\
\hline \multirow[t]{2}{*}{ BVS } & 0.958 & 0.959 & 0.972 \\
\hline & $(0.000)^{* * *}$ & $(0.000) * * *$ & $(0.000) * * *$ \\
\hline \multirow[t]{2}{*}{ EPS } & -0.3622 & -0.205 & -0.260 \\
\hline & $(.141)$ & $(0.641)$ & $(0.525)$ \\
\hline
\end{tabular}




\begin{tabular}{cccc}
\hline DPS & 9.221 & 8.076 & 9.11 \\
& $(0.000)^{* * *}$ & $(0.005)^{* * *}$ & $(0.000)^{* * *}$ \\
DY & -5.361 & -5.173 & -5.20 \\
& $(0.000)^{* * *}$ & $(0.000)^{* * *}$ & $(0.000) * * *$ \\
PE & 0.004 & 0.009 & 0.006 \\
& $(0.008)^{* * *}$ & $(0.000)^{* * *}$ & $(0.000)^{* * *}$ \\
DA & -0.044 & -0.030 & -0.047 \\
& $(0.644)$ & $(0.880)$ & $(0.642)$ \\
Log MCAP & 0.118 & 0.066 & 0.112 \\
& $(0.003)^{* * *}$ & $(0.531) * * *$ & $(0.004) * * *$ \\
Constant & -0.9587 & -0.758 & -0.980 \\
& $(0.002)^{* * *}$ & $(0.377)$ & $(0.001) * * *$ \\
$\mathrm{R}^{2}$ & 0.802 & 0.78 & 0.801 \\
No of observations & 167 & 167 & 167 \\
P>F & 0.000 & 0.000 & 0.000 \\
Wald Test & 0.000 & 0.000 & 0.000 \\
Hausman Test & & $4.21(0.8381)$ & \\
\hline
\end{tabular}

Note. ${ }^{* *}, * *, *$ denotes statistical significance at the $1 \%, 5 \%$ and $10 \%$ levels, respectively.

The regression analysis for Model 1 (POLS), which is our general model, revealed an $\mathrm{R}^{2}$ of 0.80 which means that $80 \%$ of the variation in market price in Bahrain is explained by the variables included in the study. The $\mathrm{p}$ value of F-test also shows significance at $1 \%$ level and this leads to the rejection of null hypothesis which states that all the coefficients of variables are jointly equal to zero. The coefficient of variation $(\beta)$ which explains the direction of variability is positive for ROE, BVS, DPS, PE and Log MCAP while it is negative for EPS, DY and DA respectively. The regression results showed a positive impact with significance at $1 \%$ level for ROE, BVS, DPS, PE and Log MCAP. The coefficients (p-value) for ROE, BVS, DPS, PE and Log MCAP were 1.306(0.003), $0.958(0.000), 9.221(0.000), 0.004(0.008)$ and $0.118(0.003)$ respectively. Thus our null hypotheses for the aforesaid variables are rejected at $1 \%$ significance level and the alternative hypothesis is accepted, thus documenting the positive effect of the aforesaid variables on stock price. The results were consistent with the findings of Irfan and Nishat (2002), Khan et al. (2011) and Okafor and Mgbame (2011). This shows that market value of a share is significantly and positively affected by a high return on equity, increasing book value of shares, higher dividend per share and increased price earnings per share. This suggests that an upward trend in these variables will automatically cause an increase in the market price of shares as investors show a preference for these stocks.

The variable dividend yield showed a negative relationship with market price of shares and the results were significant at $1 \%$ level. This result is consistent with the results of Baskin (1989) and Okafor and Mgbame (2011), and it suggests that investors are not affected by dividend decisions. This can be attributed to the "clientele effect" of dividend policies. The theory suggests that dividend policies affect different groups in a different ways. There are some investors who base their investment decision on dividend policies in order to get immediate benefits from their investment while some are more inclined to capital gains and would like to avoid tax on dividends. A negative relationship between EPS and market price of shares is also seen in the regression results but they are insignificant ( $\mathrm{p}$-value $=0.40$ ). This is contrary to the results obtained by Somoye, Akintoye and Oseni (2009) and Khan et al. (2011).This suggests that investors in Bahrain do not consider earnings per share (EPS) as a significant determinant of stock price as the investors are aware that EPS can increase not only because of the increase in profits but also due to stock repurchases. Therefore, it may not be an apt factor affecting investment decisions. The results also reveal a negative relationship between firms debt policy and market price of shares, however with a high level of insignificance ( $\mathrm{p}$-value $=0.585$ ). The negative coefficient reported for leverage, is however, consistent with the findings of Midani (1991) and Pani (2008). The reason for the inverse relationship can be attributed to the fact that investors do not prefer firms who have a large amount of debt as there can be chances of future insolvency due to fixed interest paying commitments. The insignificance can be attributed to the low level of importance given to this factor as a significant determinant of stock prices in the eyes of investors.

The results have been further analyzed under another model, namely the FE and RE (Model 2). From the table above it is clear that the Hausman test favored the RE estimation $(p$-value $=0.8381)$ therefore our analysis will be based on RE. The Wald test statistics reject the null hypothesis that the parameters in the regression equations 
are jointly equal to zero. The results obtained from Model 2 reveals results that are analogous with our POLS results. The $\mathrm{R}^{2}$ reported in the model is consistent with the POLS results $(0.80)$ and the similarity in the sign of coefficients for ROE, BVS, DPS, PE and Log MCAP further documents their positive and significant (p-value of all these variables $=0.001$ ) relationship with the dependent variable. Consistency with Model 1is also maintained in the direction of relationship among DY, EPS and ROE on the market price of shares as the coefficients are negative. The significant negative impact of DY and the insignificant impact of EPS and ROE with MPS further documents the accuracy of results obtained from both models.

\section{Conclusions, Recommendations and Limitations}

The main aim of this paper was to analyze the determinants of market price of shares of companies listed in the Bahrain stock exchange. Financial data for the same was retrieved for the period 2006-2010 from the Bahrain Stock exchange website. A panel data for 41 companies were constructed resulting in 167 observations. The estimation method is based on POLS regression with robust standard errors, and FE and RE models. The study mainly tried to establish a relationship between market price of shares (MPS) and eight other variables namely return on equity (ROE), book value of share (BVS), earnings per share (EPS), dividend per share (DPS), price earnings (PE), dividend yield (DY), debt to total asset (DA) and firm size (LogMCAP).

The empirical findings reveal a positive and significant relationship between ROE, BVS, DPS, PE and Log MCAP suggesting that these factors act as active determinants in shaping the market price of shares. However a significant negative relationship was found between dividend yield and MPS. This suggests that dividend decisions are made in order to attract different clienteles. Consistencies in results have been noticed in both the estimation models. Therefore, a certain group who expects short term and regular return will show their impact as a positive relationship with market price while the group who is unaffected or considers dividends as irrelevant will show an inverse relationship with stock price. Leverage also showed an inverse but insignificant relationship with market price. This can be due to the fact that investors show a general aversion towards heavily indebted companies but at the same time do not consider the inclusion of debt in the capital structure of companies as a determinant of market price.

The study acts as a guide to potential investors in Bahrain to focus on the factors discussed above before making investment decisions. It is recommended that investors monitor the PE ratio, dividend policies (DPS and DY), BVS, Log MCAP and ROE before they expand their portfolio. The paper also provides recommendations to the listed companies in Bahrain to focus their attention in taking steps to improve the figures related to the significant variables evolved in this study, affecting the market price of shares. Bahrain is an emerging economy and it is imperative to conduct studies which will benefit the investor to make rational investments. The results can be considered reliable as it has included nearly $80 \%$ of the companies listed in the Bahrain stock exchange. However, certain limitations also accrue from the study. As the paper only considers firm specific factors and excludes macro-economic factors like GDP, inflation, interest rates, business cycles etc. We cannot override the impact of these factors on the MPS. The study is based on the data set that is constructed from the publications of the IFS and IMF. The reliability and accuracy of that data will therefore, affect the robustness of the results of the present study. This opens an arena for further research to encompassing the macro and micro factors for unfolding a comprehensive idea of factors affecting MPS.

\section{References}

Al-Ajmi, J. Y. (2008). Risk Tolerance of Individual Investors in an Emerging Market. International Research Journal of Finance and Economics, 17, 15-26.

Allahawiah, S., \& Al-Amro, S. (2012). Factors affecting Stock Market Prices in Amman Stock Exchange: A Survey Study. European Journal of Business and Management, 4(8), 236-245.

Allen, D. E., \& Rachim, V. S. (1996). Dividend Policy and Stock Price Volatility: Australian Evidence. Journal of Applied Economics, 6, 175-188.

Al-Malkawi, N. H., \& Abdullah, N. (2011). Finance-Growth Nexus: Evidence from a Panel of MENA Countries. International Research Journal of Finance and Economics, 69, 129-139.

Al-Qenae, R., Li, C., \& Wearing, B. (2002). The Information Content of Earnings on Stock Prices: The Kuwait Stock Exchange. Multinational Finance Journal, 6(3\&4), 197-221.

Al-Tamimi, H. A. H., Alwan, A. A., \& Rahman, A. A. A. (2011). Factors Affecting Stock Prices in the UAE Financial Markets. Journal of Transnational Management, 16(1), 3-19. http://dx.doi.org/10.1080/15475778.2011.549441 
Balkrishnan. (1984). Determinants of Equity Prices in India. Management Accountant, 19(12), 728-730.

Baltagi, B. H. (2001). Econometrics Analysis of Panel Data. Chichester: Wiley.

Baskin, J. (1989). Dividend Policy and the Volatility of Common Stock. Journal of Portfolio Management, 3(15), 19-25. http://dx.doi.org/10.3905/jpm.1989.409203

Black, F., \& Scholes, M. (1974). The Effect of Dividend Yield and Dividend Policy on Common Stock Prices and Returns. Journal of Financial Economics, 1(1), 1-22. http://dx.doi.org/10.1016/0304-405X(74)90006-3

Capstaff, J., Klaeboe, A., \& Marshall, A. P. (2004). Share Price Reaction to Dividend Announcements: Evidence from the signaling model from the Oslo Stock Exchange. Multinational Finance Journal, 8(1\&2), 115-139.

Chaudhuri, K., \& Smiles, S. (2004). Stock Market and Aggregate Economic Activity: Evidence from Australia. Applied Financial Economics, 14, 121-129. http://dx.doi.org/10.1080/0960310042000176399

Chen, J., \& Dhiensiri, N. (2009). Determinants of Dividend Policy: The Evidence from New Zealand. International Research Journal of Finance and Economics, 34, 18-28.

Collins, J. (1957). How to Study the Behavior of Bank Stocks. The Analysts Journal, 13(2), 109-113. http://dx.doi.org/10.2469/faj.v13.n2.109

Das, N., \& Pattanayak, J. K. (2007). Factors affecting Market Price of SENSEX shares. The Icfai Journal of Applied Finance, 13(8), 33-51.

Denis, D. J., \& Osobov, I. (2008). Why Do Firms Pay Dividends? International Evidence on the Determinants of Dividend Policy. Journal of Financial Economics, $89(1)$, http://dx.doi.org/10.1016/j.jfineco.2007.06.006

Drury, C. (2008). Management and Cost Accounting (7th ed.). London: Cengage learning. http://dx.doi.org/10.1007/978-1-4899-6828-9

Graham, R. E., \& Dodd, P. (1951). Security Analysis.USA: McGraw-Hill.

Greene, W. H. (2008). Econometric analysis (6th ed.). USA: Prentice Hall.

Hussainey, K., Mgbame, C. O., \& Chijoke-Mgbame, A. M. (2011). Dividend policy and share price volatility: UK evidence. Journal of Risk Finance, 12(1), 57-68. http://dx.doi.org/10.1108/15265941111100076

Irfan, C. M., \& Nishat, M. (2002). Key Fundamental Factors and Long-run Price Changes in an Emerging Market - A Case Study of Karachi Stock Exchange. The Pakistan Development Review, 41(4), 517-533.

Khan, K. I., Aamir, M., Qayyum, A., Nasir, A., \& Khan, M. I. (2011). Can Dividend Decisions Affect the Stock Prices: A Case of Dividend Paying Companies of KSE. Journal of Finance and Economics, 76, 67-74.

Midani, A. (1991). Determinants of Kuwait Stock Prices: An Empirical Investigation of Industrial, Services and Food Company Shares. Joumal of Administrative Sciences and Economics, 2, 304-312.

Mukherjee, T. K., \& Atsuyuki, N. (1995). Dynamic Relations Between Macroeconomic Variables and the Japanese Stock Market: An Application of vector error correction model. The Journal of Financial Research, 18(2), 223-237. http://dx.doi.org/10.1111/j.1475-6803.1995.tb00563.x

Nirmala, P. S., Sanju, P. S., \& Ramachandran, M. (2011). Determinants of Share Price in India. Journal of Emerging Trends in Economics and Management Sciences, 2(2), 124-130.

Okafor, C. A., \& Mgbame, C. O. (2011). Dividend Policy and Share Price Volatility in Nigeria. Jorind, 9, 202-210.

Pani, U. (2008). Dividend Policy and Stock Price Behaviour in Indian Corporate Sector: A panel data approach. Retrieved from http://www.igidr.ac.in/money/mfc-12/Coporate_Dividendpolicy_and_stock_price_behaviour_upananda\%20 pani.pdf

Park, H. M. (2009). Linear Regression Models for Panel Data Using SAS, Stata, LIMDEP and SPSS. Working paper. The University Information Technology Services (UITS) Center for Statistical and Mathematical Computing, Indiana University.

Rashid, K. (2008). A Comparison of Corporate Governance and Firm Performance in Developing (Malaysia) and Developed (Australia) Financial Markets. Published Doctoral Dissertation, Victoria University. Melbourne.

Rudd, K. (2009). The Global Financial crisis. The Monthly (The Australian politics, society \& culture). Australia. 
Sharma, S. (2011). Determinants of Equity Share Prices in India. Journal of Arts, Science and Commerce, 2(4), 51-60.

Somoye, R., Akintoye, I., \& Oseni, J. (2009). Determinants of Equity Prices in the Stock Markets. International Research Journal of Finance and Economics, 30, 177-189.

Uddin, H. (2003). Effect of Dividend Announcement on Shareholders' Value: Evidence from Dhaka Stock Exchange. Journal of Finance.

Verbeek, M. (2000). A Guide to Modern Econometrics. Brisbane: John Wiley \& Sons Ltd.

Zahir, M. A., \& Khanna, Y. (1982). Determinants of Stock Prices in India. The Chartered Accountant, 30(8), 521-523.

Zhao, X. Q. (1999). Stock prices, Inflation and Output: Evidence from China. Applied Economics Letters, 6(8), 509-511. http://dx.doi.org/10.1080/135048599352835

\section{Copyrights}

Copyright for this article is retained by the author(s), with first publication rights granted to the journal.

This is an open-access article distributed under the terms and conditions of the Creative Commons Attribution license (http://creativecommons.org/licenses/by/3.0/). 